Piwulang 8(1)(2020)
Teaching
http://journal.unnes.ac.id/sju/index.php/piwulang

\title{
PENGEMBANGAN MEDIA PEMBELAJARAN BAHASA JAWA MATERI UPACARA ADAT MANTU BERBASIS ANDROID DI SMK PANCA BHAKTI BANJARNEGARA
}

\author{
Imelda Dian Pertiwi ${ }^{1}$, Bambang Indiatmoko $^{2}$, Teguh Supriyanto ${ }^{3}$ \\ 1,2,3 Jurusan Bahasa Jawa, Fakultas Bahasa dan Seni, Universitas Negeri Semarang, Indonesia \\ Corresponding Author: imeldadianpertiwi@gmail.com ${ }^{1}$
}

\begin{abstract}
Abstrak
Memahami isi teks eksposisi tentang tradisi adat mantu salah satu kompetensi dasar yang terdapat dalam standar isi mata pelajaran bahasa Jawa. Akan tetapi, harapan tersebut tidak diimbangi dengan ketersediaan alat penunjang pembelajaran yang kontekstual sesuai dengan kebutuhan. Hal ini membuat siswa merasa bosan dan kurang memahami materi dengan baik. Tujuan penelitian ini adalah 1) mengetahui kebutuhan siswa dan guru mengenai pengembangan media pembelajaran upacara adat mantu berbasis android, 2) mengembangan media pembelajaran upacara adat mantu berbasis android, dan 3) membuat prototipe pengembangan media pembelajaran upacara adat berbasis android. Penelitian ini menggunakan pendekatan pengembangan (Research and Development). Prosedur penelitian ini yaitu 1) analisis potensi dan masalah, 2) mengumpulkan data, 3) desain produk, 4) validasi desain/uji ahli, dan 5) revisi. Data yang diperoleh menggunakan 1) wawancara, dan 2) angket. Teknik analisis data pada penelitian ini menggunakan teknik deskriptif kualitatif. Hasil penelitian ini menunjukan bahwa guru dan siswa membutuhkan sebuah media pembelajaran upacara adat berbasis android. Media ini berisi 1) materi upacara adat mantu, 2) tata cara upacara adat mantu, 3) gladhen tentang materi upacara adat mantu. Hasil uji validasi prototipe media pembelajaran upacara adat berbasis android ini sudah pantas dan layak digunakan untuk siswa dan guru. Media ini dikemas atau dicetak dalam bentuk aplikasi android.
\end{abstract}

Kata Kunci: pengembangan, upacara adat, android

\begin{abstract}
Understanding the contents of the exposition text about the traditional of mantu is one of the basic competencies contained in the standard content of Javanese language subjects. This makes students feel bored and lack understanding of the material well. The purpose of this study is 1) to find out the needs of students and teachers regarding the development of android-based mantu traditional ceremonial learning media, 2) to develop learning media for android-based mantu traditional ceremonies, and 3) to make prototypes for developing traditional ceremonies based on android. This research uses a development (Research and Development) approach. The procedure of this study is 1) analysis of potential and problems, 2) collecting data, 3) product design, 4) design validation / expert testing, and 5) revisions. Data obtained using 1) interview, and 2) questionnaire. The data analysis technique in this study used qualitative descriptive techniques. The results of the validation test for prototypes of traditional ceremonial learning based on Android are appropriate and appropriate for students and teachers. This media is packaged or printed in the form of an android application.
\end{abstract}

Keywords: development, traditional ceremony, android

(C) 2020 Universitas Negeri Semarang

p-ISSN 2252-6307

e-ISSN 2714-867X 
Imelda Dian Pertiwi, dkk/ Piwulang 8 (1) (2020)

\section{PENDAHULUAN}

Materi yang akan peneliti paparkan pada media pembelajaran berbasis android ini salah satunya materi upacara adat yang mempunyai pengertian yaitu suatu upacara yang dilakukan secara turuntemurun yang berlaku di suatu daerah. Karena di SMK Panca Bhakti Banjarnegara media pembelajaran yang digunakan masih tergolong kuno hanya menggunakan teks fotocopy yang ada dibuku lain ataupun internet. Bahkan untuk dua tahun ini sekolah sudah tidak diperbolehkan untuk menggunakan LKS, dan itu sangat menyusahkan peserta didik dalam pembelajaran.

Adanya media pembelajaran berbasis android ini diharapkan pengetahuan siswa mengenai upacara adat akan bertambah, sehungga kelak mampu menjaga dan melestarikan upacara adat tersebut. Dengan demikian, aset budaya berupa upacara adat tidak akan hilang dan tetap ada hingga generasi berikutnya.

Menurut Anderson (Sukiman, 2012:

28-29) menjelaskan media pembelajaran adalah media yang memungkinkan terwujudnya hubungan langsung antara karya seseorang pengembang mata pelajaran dengan para siswa. Media pembelajaran adalah segala sesuatu yang dapat digunakan untuk menyalurkan pesan dari pengirim ke penerima sehingga merangsang pikiran, perasaan, perhatian dan minat serta kemauan peserta didik sedemikian rupa sehingga proses belajar terjadi dalam rangka mencapai tujuan pembelajaran secara efektif.
Sementara itu, Gerlach dan Ely (Azhar Arsyad, 2011: 3), menjelaskan bahwa media apabila dipahami secara garis besar adalah manusia, materi, atau kejadian yang membangun kondisi yang membuat siswa mampu memperoleh pengetahuan, keterampilan, dan sikap. Selain itu, media merupakan salah satu komponen komunikasi, yaitu sebagai pembawa pesan dari komunikator menuju komunikan.

Dari beberapa pendapat mengenai pengertian media di atas, dapat disimpulkan bahwa media pembelajaran adalah segala sesuatu (alat dan bahan) yang dapat digunakan dalam kegiatan pembelajaran untuk menyalurkan pesan dari pengirim (guru) ke penerima (siswa) sehingga siswa mampu memperoleh pengetahuan, keterampilan atau sikap.

Dalam penelitian ini, pengembangan media yang akan dilakukan adalah multimedia (aplikasi game). Ada beberapa prinsip yang perlu diperhatikan dalam mengembangkan multimedia. Menurut Azhar Arsyad (2011: 107112) prinsip-prinsip visual tersebut adalah (1) kesederhanaan, secara umum mengacu pada jumlah elemen yang terkandung dalam suatu visual. Jumlah elemen yang lebih sedikit memudahkan siswa menangkap dan memahami pesan yang disajikan visual tersebut.

Dan analisis tersebut, peneliti tertarik untuk melakukan penelitian dan pengembangan dengan judul "Pengembangan Media Pembelajaran Bahasa Jawa Materi Upacara Adat Berbasis Android Di SMK Panca Bhakti Banjarnegara". 
Imelda Dian Pertiwi, dkk/ Piwulang 8 (1) (2020)

Sesuai dengan uraian di atas, rumusan masalah dalam penelitian ini adalah (1) bagaimana kebutuhan siswa dan guru terhadap media pembelajaran upacara adat berbasis android? (2) bagaimana pengembangan media pembelajaran upacara adat berbasis android? dan (3) bagaimana prototipe media pembelajaran upacara adat berbasis android?

\section{METODE PENELITIAN}

Jenis penelitian yang digunakan oleh peneliti adalah penelitian Research and Development (R\&D), merupakan metode penelitian yang bertujuan untuk menghasilkan suatu produk tertentu dan menguji keefektifan produk tersebut (Sugiyono, 2010:407).

Model pembelajaran yang akan peneliti gunakan sebagai acuan yakni model pengembangan Borg \& Gall. Langkah penelitian yang digunakan mengacu pada langkah-langkah penelitian R\&D yang dikemukakan oleh Borg dan Gall (Sugiyono 2009:298) yaitu, (1) potensi dan Masalah, (2) pengumpulan data, (3) desain produk, (4) validasi desain, (5) revisi desain, (6) uji coba produk, (7) revisi produk, (8) ujicoba pemakaian, (9) revisi produk, dan (10) produksi masal. Dalam penelitian ini langkah-langkah penelitian pengembangan hanya sampai pada proses revisi produk atau desain, sehingga disederhanakan menjadi lima langkah.

Data yang dibutuhkan dalam penelitian ini adalah (1) data yang berkaitan dengan kebutuhan siswa dan guru terhadap media pembelajaran upacara adat berbasis android, (2) data yang berkaitan dengan materi upacara adat, (3) data hasil uji validasi prototipe media pembelajaran upacara adat berbasis android berupa koreksi dan saran dari ahli. Ketiga data tersebut diperoleh dari beberapa sumber yang berbeda, yaitu siswa beserta guru kelas XI di SMK Panca Bhakti Banjarnegara serta ahli.

Pengumpulan data pada penelitian pengembangan ini menggunakan (1) teknik wawancara, dilakukan dengan mengajukan beberapa pertanyaan kepada guru untuk memperoleh informasi terkait kebutuhan yang menjadi alasan perlunya membuat media pembelajaran upacara adat berbasis andorid dalam pembelajaran bahasa Jawa di sekolah. (2) angket, merupakan suatu alat pengumpulan data yang dilakukan secara tidak langsung bertanya kepada responden melainkan mengisi pertanyaan-pertanyaan yang ada di dalam instrumen tersebut untuk memperoleh data atau informasi dari siswa tentang kebutuhan terhadap media pembelajaran upacara adat berbasis android. (3) lembar penilaian uji validasi nantinya akan diisi oleh ahli materi dan ahli media, di dalamnya berisi borang penilaian, saran, serta masukan.

\section{HASIL DAN PEMBAHASAN}

Hasil Analisis Kebutuhan Siswa dan Guru terhadap Media Pembelajaran Upacara Adat berbasis Android

Hasil analisis kebutuhan siswa terhadap media pembelajaran upacara adat berbasis android dengan menyebar angket yang ditujukan kepada siswa kelas XI di SMK Panca Bhakti 
Imelda Dian Pertiwi, dkk/ Piwulang 8 (1) (2020)

Banjarnegara. Angket ini bertujuan untuk mengetahui seberapa besar kebutuhan siswa terhadap prototipe yang akan dikembangkan oleh peneliti. Jawaban dari responden dapat dijadikan sebagai pedoman dalam penyusunan media pembelajaran upacara adat berbasis android.

Dari hasil angket kebutuhan di sekolah yaitu SMK Panca Bhakti Banjarnegara, sebanyak 18 siswa dari total 30 kelas XI yang dijadikan sebagai responden mengalami kesulitan dalam kegiatan pembelajaran bahasa Jawa, karena guru masih menggunakan metode konvensional yaitu ceramah dan kurang memanfaatkan media pembelajaran yang tersedia di sekolah. Perkembangan zaman yang pesat seperti saat ini membuat hampir seluruh siswa terpacu pada smartphone yang mereka miliki, bahkan mereka menggunakan smartphone tersebut didepan guru pada saat pembelajaran.siswa yang merasa jenuh dan bosan lebih memilih mengakses smarthphone tersebut daripada mendengarkan penjelasan guru, misalnya memutar music dengan menggunakan headset, bermain game, dan mengakses media sosial lainnya.

Dalam proses pembelajaran bahasa Jawa sendiri siswa dalam setiap kelas berbeda dan masih mengalami kesulitan dalam berbahasa sehingga guru harus menerjemahkan setiap kalimat yang tidak dimengerti oleh siswa kedalam bahasa Indonesia. Selain itu kendala yang dihadapi guru adalah guru harus menyelesaikan masalah tersebut dengan menjelaskan satu persatu tentang upacara adat dengan bahasa ngoko bahkan satu persatu.
Sebanyak 27 siswa dari jumlah total 31 dalam satu kelas XI yang dijadikan sebagai responden menjawab guru masih menggunakan media pembelajaran secara manual. Jika dikembangkannya media pembelajaran upacara adat berbasis android sebanyak 24 siswa memilih agar produk tersebut dibuat, sedangkan 7 siswa tidak memilih media pembelajaran menggunakan android dengan alasan tertentu. Dengan demikian, jawaban yang lebih banyaklah yang dijadikan acuan peneliti dalam mengembangkan media pembelajaran upacara adat berbasis android.

Berkurangnya minat belajar siswa akibat lebih tertarik dengan smartphone maka peneliti membuat media pembelajaran yang memanfaatkan smartphone. Smartphone yang digunakan menggunakan sistem operasi android. Sistem operasi android dipilih karena sistem ini adalah sistem yang paling banyak digunakan daripada sistem operasi yang lain. Media pembelajaran itu sendiri digunakan oleh siswa secara mandiri dan selain itu guru juga bisa menggunakannya dengan bantuan laptop/PC dan LCD.

Ketiga narasumber pernah menemukan bacaan cerita rakyat lokal Kabupaten Brebes akan tetapi tidak lebih dari lima cerita.

Jika disusunnya buku bacaan kumpulan cerita rakyat Kabupaten Brebes, nilai moral yang sesuai dengan kebutuhan dalam pembentukan karakter siswa menurut pendapat guru yang telah diwawancarai yaitu nilai moral individual, sosial, religi dan rasa tanggung jawab. Para guru sangat setuju apabila buku kumpulan cerita rakyat Kabupaten Brebes disusun menggunakan dua 
Imelda Dian Pertiwi, dkk/ Piwulang 8 (1) (2020)

bahasa yakni menggunakan bahasa Jawa dialek Brebes dan bahasa Indonesia sebagai terjemahannya. Sesuai pendapat ketiga narasumber, penggunaan kalimat dalam buku bacaan kumpulan cerita rakyat yang akan disusun, yaitu menggunakan kalimat sederhana, singkat, padat dan jelas agar mudah dipahami siswa.

Berdasarkan data angket kebutuhan dan wawancara terhadap guru di SMK Panca Bhakti Banjarnegara media pembelajaran hanya di dapatkan dari internet atau youtube saja bahkan guru belum pernah menemukan media pembelajaran materi upacara adat menggunakan sistem android karena hampir sebagian besar media pembelajaran yang menggunakan sistem android adalah pembelajaran aksara Jawa. Sedangkan ke aktifan kelas sendiri menurut guru yang telah diwawancarai yaitu bergantung terhadap kelas, karena kebanyakan siswa SMK adalah siswa laki-laki maka hal itu sangat mempengaruhi terhadap pembelajaran salah satunya.

Jika dikembangkannya media pembelajaran upacara adat berbasis android menurut angket kebutuhan dan wawancara guru yaitu siswa akan lebih antusias dan tertarik untuk mempelajari materi upacara adat dengan adanya media tersebut. Selain itu harapannya, media pembelajaran yang akan dikembangkan bisa mengikuti perkembangan zaman, supaya siswa lebih semangat dan tertarik dalam mengikuti pembelajaran dan materi yang akan terserap baik dengan adanya media pembelajaran upacara adat berbasis android.
Prototipe Media Pembelajaran Upacara Adat berbasis Android

Pembuatan media pembelajaran berbasis android peneliti menggunakan software Adobe Flash CS6 dan Adobe Ilustrator.

Tampilan awal, pada tampilan ini terdiri atas judul, menu untuk gladhen, menu mulai, dan menu babagan. Menu gladhen disini nanti akan berisi soal-soal tentang upacara adat mantu sebagai latihan soal untuk para siswa. Sedangkan menu mulai disini untuk memulai pada menu kedua media pembelajaran upacara adat berbasis android yang didalamnya terdapat sub menu lainnya dan terdapat juga menu babagan yang berisi profil peneliti. Pada tampilan ini terdapat suara rekaman yang berbunyi "Ayo Sinau Tradhisi Mantu" yang akan menarik minat siswa agar tertarik untuk menggunakan media pembelajaran upacara adat berbasis android tersebut.

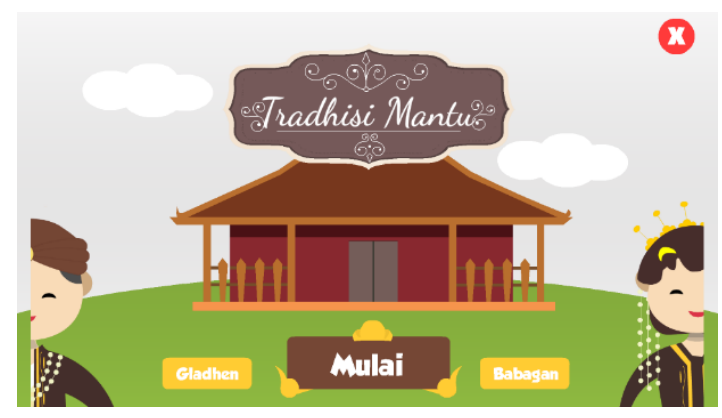

Gambar 1. Tampilan Awal Media Pembelajaran berbasis Android

Kedua, gladhen, menu gladhen disini akan menyajikan beberapa latihan soal untuk siswa, dan setelah siswa menjawab akan langsung bisa mendapatkan koreksi dari jawaban tersebut. 
Imelda Dian Pertiwi, dkk/ Piwulang 8 (1) (2020)

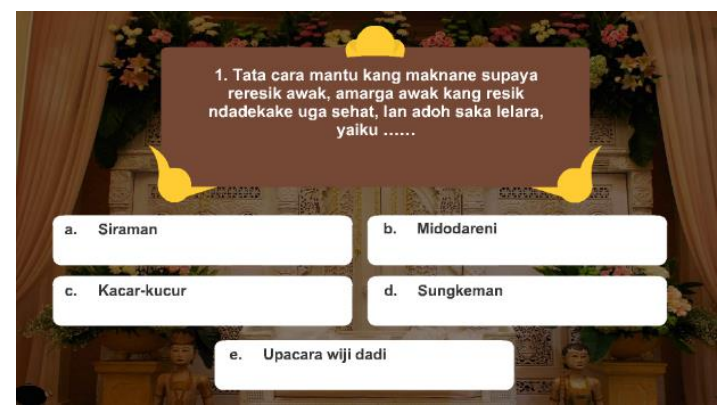

Gambar 2. Tampilan Gladhen Media Pembelajaran berbasis Andorid

Ketiga. babagan, pada menu babagan akan berisi profil peneliti, isi dari menu babagan sendiri adalah nama, tanggal lahir, nama universitas dan semesternya, foto profil peneliti serta beberapa contact person seperti instagram dan line.

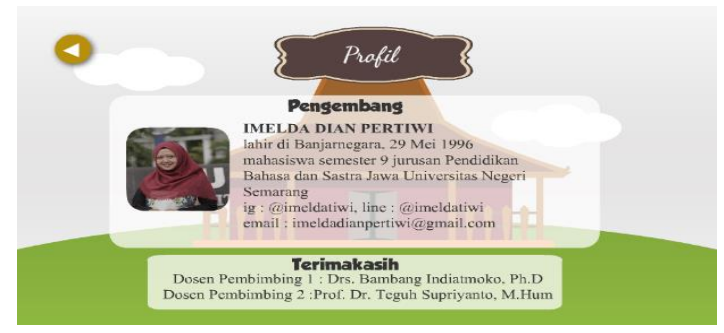

Gambar 3. Tampilan Profil Peneliti

Keempat, main menu, terdapat beberapa sub menu dari menu awal sebelumnya. Sub menu disini terdapat menu materi, $\mathrm{KI} / \mathrm{KD}$, dan tata cara. Setiap menunya akan mempunyai fungsi sendiri-sendiri yang akan mnegarahkan pengguna kepada inti menu tersebut.

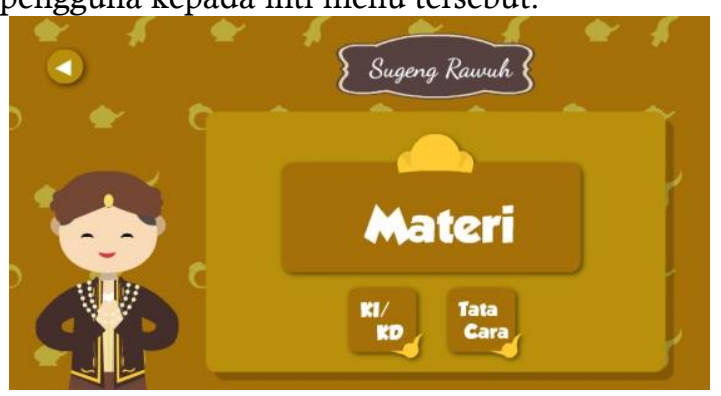

Gambar 4. Tampilan Menu Media Pembelajaran berbasis Android
Kelima, materi, sub menu materi disini berisi materi upacara adat mantu yang terdiri dari pengertian upacara adat secara umum, langkahlangkah upacara adat, dan jenis-jenis upacara adat. Pada materi pengertian upacara adat secara umum hanya terdapat beberapa kalimat yang menjelaskan upacara adat itu sendiri, sedangkan pada materi langkah-langkah upacara adat mantu akan disajikan beberapa foto dan animasi yang menjelaskan setiap langkah-langkahnya. Selain itu pada materi jenis-jenis upacara adat juga akan terdapat beberapa jenis upacara adat selain upacara adat mantu dan akan disertakan fotonya disetiap jenis upacara adatnya.

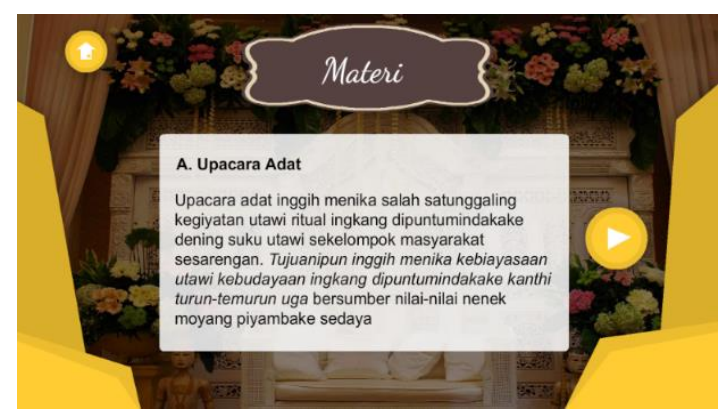

Gambar 5. Tampilan Materi Awal Media Pembelajaran berbasis Android

Keenam, sub menu materi, pada bagian sub menu materi ini peneliti menyajikan daftar menu tahapan tata cara upacara adat mantu agar pengguna lebih mudah untuk mengulang materi tersebut.

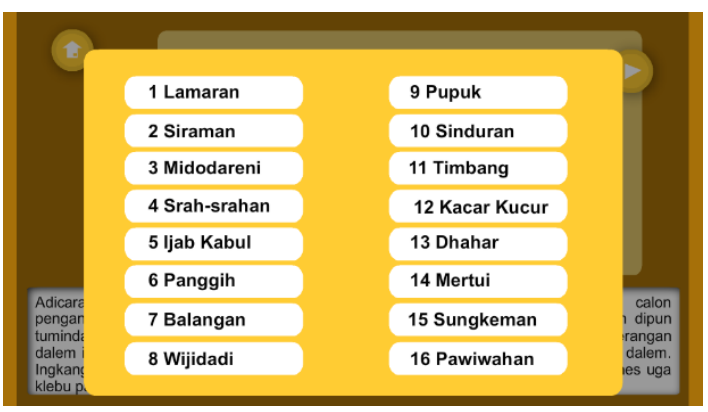

Gambar 6. Tampilan Sub Menu Materi Tata Cara Upacara Adat Mantu 
Imelda Dian Pertiwi, dkk/ Piwulang 8 (1) (2020)

Ketujuh, KI/KD, pada sub menu $\mathrm{KI} / \mathrm{KD}$ berisi Kompetensi Inti dan Kompetensi Dasar sesuai dengan permenag. Kompetensi Inti dan Kompetensi Dasar bertujuan untuk menunjukan apa yang harus dicapai siswa dalam pembelajaran ini.

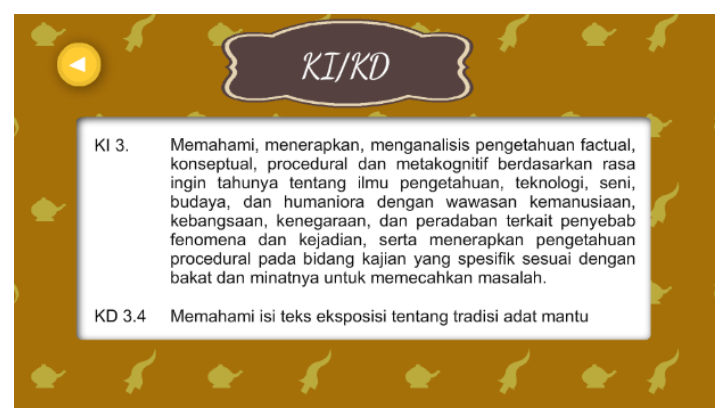

Gambar 7. Tampilan KI/KD

Kedelapan, tata cara, sub menu tata cara disini adalah untuk menjelaskan cara pemakain media pembelajaran upacara adat berbasis android ini sendiri. Karena ada beberapa bagian yang dibuat sebagai media interaktif agar siswa tidak merasa bosan dengan tulisan dan gambar yang disajikan peneliti.

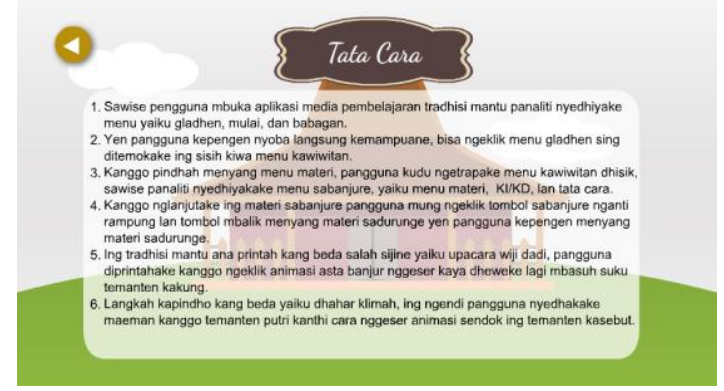

Gambar 8. Tampilan Menu Tata Cara Upacara Adat Mantu

Kesembilan, simpulan, pada media pembelajaran upacara adat mantu berbasis android ini selain menyajikan materi dan tata cara upacara adat mantu, peneliti juga menyajikan simpulan dari pembelajaran upacara adat mantu agar siswa lebih memahami inti dari materi tersebut.

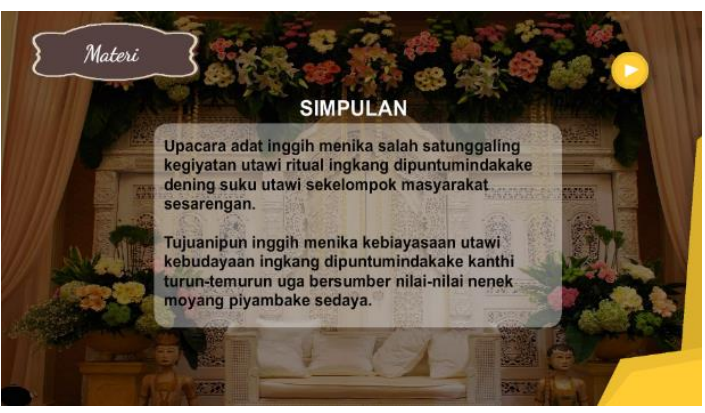

Gambar 9. Tampilan Simpulan Pembelajaran Upacara Adat Mantu

Sepuluh, penutup, mempunyai dua pilihan yaitu "Nggih" dan "Boten" dimana pengguna bisa memilih untuk keluar dari media pembelajaran atau tidak.

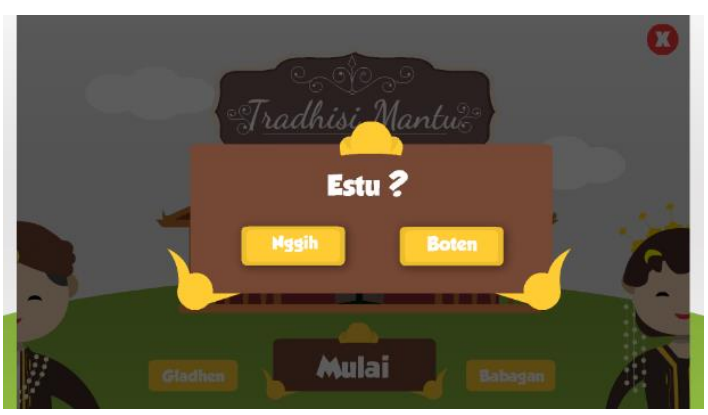

Gambar 10. Tampilan menu penutup

\section{Validasi Prototipe Buku Pengayaan Cerita Rakyat Dua Bahasa}

Prototipe pengembangan media pembelajaran upacara adat mantu berbasis android ini ditelaah dan dikonsultasikan kepada ahli media dan materi supaya hasilnya jauh lebih baik lagi. Bimbingan dan arahan yang diberikan oleh dosen pembimbing menjadi penyempurna media pembelajaran upacar adat berbasis android tersebut.

Pada bagian ini akan dibahas tentang bentuk prototipe pengembangan media 
Imelda Dian Pertiwi, dkk/ Piwulang 8 (1) (2020)

pembelajaran upacara adat berbasis android sesudah proses uji validasi media, maupun uji validasi materi. Berikut ini pemaparannya.

Ahli media dalam penelitian ini adalah adalah Bapak Zuwanto, S.Kom. Beliau merupakan guru sekaligus ketua jurusan Teknik Komputer dan Jaringan (TKJ) yang mengampu mata pelajaran mengenai desain komputer dan aplikasi dan perancangan jaringan. Ahli media tesebut menilai prototipe media pembelajaran upacara adat berbasis android ini aspek kelayakan grafis. Berikut ini merupakan perbaikan aspek kelayakan grafis sesuai saran dari ahli media (1) Tombol KI/KD dan tata cara terlalu pendek, (2) Background pada menu tahapan upacara adat mantu terlalu polos, (3) Ukuran gambar terlalu kecil.

Adapun penjabaran hasil uji validasi media terhadap prototipe media pembelajaran upacara adat berbasis android dapat dilihat sebagai berikut.

Saran dari Bapak zuwanto selaku ahli media perototipe ini yaitu tombol $\mathrm{KI} / \mathrm{KD}$ pada tampilan menu kedua dari media pembelajaran, sebaiknya lebih diperpanjang lagi supaya sama dengan tampilan tombol materi pada menu. Setelah melalui uji validasi, tampilan tombol $\mathrm{KI} / \mathrm{KD}$ mengalami perbaikan sesuai yang diberikan oleh ahli media. Berikut merupakan gambar tombol $\mathrm{KI} / \mathrm{KD}$ pada media pembelajaran upacara adat berbasis android sebelum dan sesudah revisi

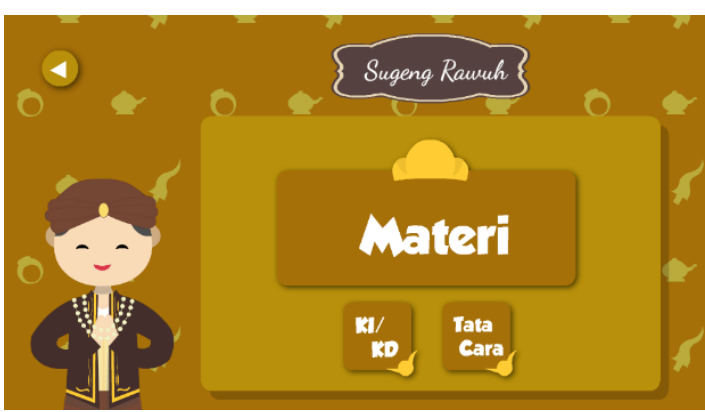

Gambar 11. Tampilan Menu Media Pembelajaran berbasis Android Sebelum Revisi

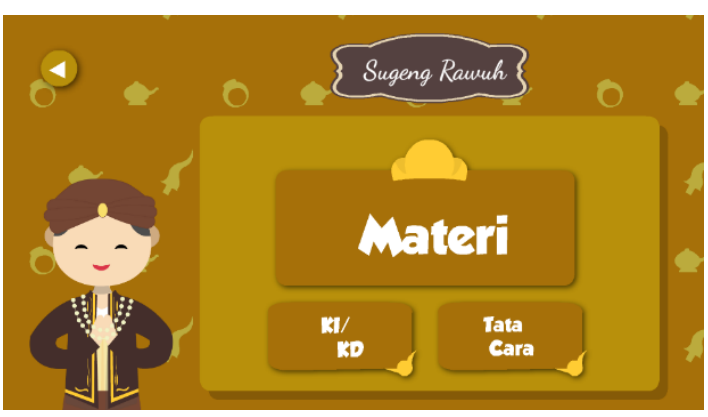

Gambar 12. Tampilan Menu Media Pembelajaran berbasis Android Setelah Revisi

Selain itu, pada salah satu background menu tahapan upacara adat perlu diperbaiki karena terlalu polos. Desain background tersebut dapat dilihat pada gambar berikut ini.

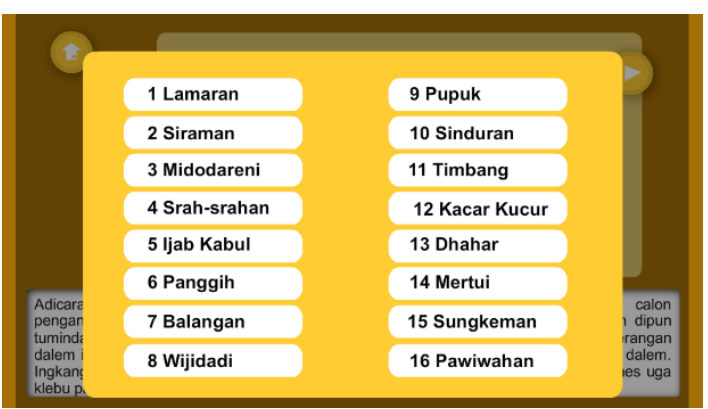

Gambar 13. Tampilan Sub Menu Materi Tata Cara Upacara Adat Mantu Sebelum Revisi

Sebelum uji validasi background tersebut hanya berwarna kuning polos. Menurut ahli media, desain background dianggap kurang menarik. Setelah diperbaiki, latar desain 
Imelda Dian Pertiwi, dkk/ Piwulang 8 (1) (2020)

background diberi gambar yang berlatar desain pernikahan. Hasil revisi desain background dapat dilihat pada gambar berikut

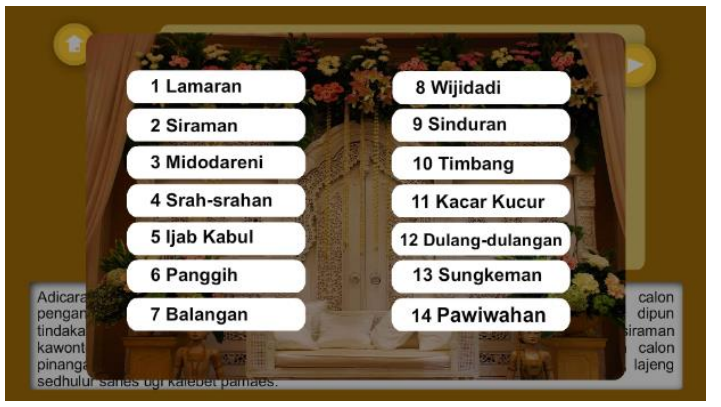

Gambar 14. Tampilan Sub Menu Materi Tata Cara Upacara Adat Mantu Setelah Revisi

Saran yang terakhir, yaitu penyajian gambar pada media pembelajaran upacara adat berbasis android yang terlalu kecil. Hal ini dilakukan supaya gambar pada media terlihat tampak lebih jelas lagi dilihat oleh pembaca. Pada kali ini penelliti tidak menggunakan saran dari ahli media dikarenakan presisi gambar sudah sesuai dengan jumlah ruang yang ada pada layar tampilan media pembelajaran upacara adat berbasis android.

Berdasarkan aspek pemilihan kata, beliau memberikan saran agar bahasa yang digunakan perlu memperhatikan dialek. Beliau juga memberikan saran agar media pembelajaran upacara adat berbasis android ini dapat digunakan di seluruh sekolah sebaiknya menggunakan bahasa krama. Akan tetapi saran ini oleh peneliti tidak digunakan, sebab peneliti sudah menggunakan bahasa krama dari awal. Setelah melakukan proses uji validasi materi menurut ahli media ada beberapa perbaikan pada penggunaan kata yang kurang sesuai. Pada media pembelajaran upacara adat berbasis android ditemukan kata yang masih menggunakan bahasa Indonesia. Pemilihan kata yang masih perlu perbaikan yaitu kata mulai yang diganti dengan kata wiwit pada menu awal dan kata estu diganti degan kata medal pada tampilan menu keluar media pembelajaran.

\section{SIMPULAN}

Berdasarkan penelitian terhadap Pengembangan Media Pembelajaran Bahasa Jawa Materi Upacara Adat berbasis Android yang telah dilaksanakan, maka simpulan dari penelitian ini adalah (1) siswa dan guru membutuhkan media pembelajaran upacara adat berbasis android. Guru membutuhkan media pembelajaran sebagai penunjang pembelajaran di sekolah, sedangkan siswa membutuhkan media pembelajaran untuk mempermudah memahami materi yang disampaikan oleh guru. Media pembelajaran upacara adat yang dibutuhkan siswa dan guru adalah media upacara adat yang lebih update dan mengikuti zaman dan berbentuk animasi. Melalui media ini, siswa dapat belajar upacara adat, (2) prototipe media pembelajaran bahasa Jawa materi upacara adat berbasis android untuk kelas XI yang memuat materi upacara adat secara umum, langkah-langkah upacara adat mantu, dan jenis-jenis upacara adat. Media ini tediri dari beberapa menu antara lain menu kompetensi dasar dan kompetensi inti, menu materi, menu kuis, dan menu tentang untuk profil peneliti. Uji validasi dilakukan oleh ahli media dan ahli materi. Berdasarkan penilaian ahli materi, media ini dinyatakan layak sebagai media pembelajaran upacara adat berbasis android. Hasil uji validasi ahli media 
Imelda Dian Pertiwi, dkk/ Piwulang 8 (1) (2020)

pembelajaran upacara adat berbasis android memberikan saran perbaikan agar media yang dihasilkan menjadi lebih baik lagi, (3) media Pembelajaran yang dihasilkan dari penelitian ini adalah media pembelajaran upacara adat berbasis android. Media pembelajaran ini dapat digunakan sebagai media pembelajaran upacara adat untuk siswa kelas XI di SMK Panca Bhakti Banjarnegara. Media pembelajaran upacara adat berbasis android dapat dijadikan guru alat penunjang pembelajaran juga dapat membantu siswa dalam memahami materi yang disampaikan.

\section{DAFTAR PUSTAKA}

Arsyad, Azhar. 2011. Media Pembelajaran. Jakarta: Raja Grafindo Persada.

Lauren, Glenn. Murtiwiyati. 2013. "Rancang Bangun Aplikasi Pembelajaran Budaya Indonesia Untuk Anak Sekolah Dasar Berbasis Android". Jurnal Ilmiah Komputasi". Desember, ISSN: 14129434, Volume 12, Nomor 2, H1m 1-10. Depok: Universitas Gunadarma.

Luthfi, Muhammad Irfan. 2016. Pengembangan Aplikasi Historoid Berbasis Android Sebagai Media Pembelajaran Sejarah Siswa SMA. Skripsi. Universitas Negeri Yogyakarta, Yogayakarta.

Muqarrobin, Kuswanto. 2016. "Development of an android-based physics e-book to ease students'physics learning And its influence on their learning achievement". American Journal of Engineering Reseacrh (AJER)". Volume 5, Hlm. 223229. Yogyakarta: Universitas Negeri Yogyakarta.
Sugiyono. 2008. Metode Penelitian Kuantitatif, Kualitatif, dan R\&D. Bandung: Alfabeta.

Sukiman. 2012. Pengembangan Media Pembelajaran. Yogyakarta: PT Pustaka Insan Madani. 